\title{
Antiproliferative and Cytotoxic Activity of Xanthohumol and Its Non-Estrogenic Derivatives in Colon and Hepatocellular Carcinoma Cell Lines
}

\author{
Isabelle E. Logan 1므, Cristobal L. Miranda ${ }^{2}$, Malcolm B. Lowry ${ }^{3}$, Claudia S. Maier ${ }^{4}$, \\ Jan F. Stevens ${ }^{2}$ (D) and Adrian F. Gombart ${ }^{2, *(D)}$ \\ 1 Department of Biochemistry and Biophysics, Linus Pauling Institute, Oregon State University, Corvallis, \\ OR 97331, USA; logani@oregonstate.edu \\ 2 Department of Pharmaceutical Sciences, Linus Pauling Institute, Oregon State University, Corvallis, \\ OR 97331, USA; Cristobal.Miranda@oregonstate.edu (C.L.M.); fred.stevens@oregonstate.edu (J.F.S.) \\ 3 Department of Microbiology, Linus Pauling Institute, Oregon State University, Corvallis, OR 97331, USA; \\ Malcolm.Lowry@oregonstate.edu \\ 4 Department of Chemistry, Oregon State University, Corvallis, OR 97331, USA; \\ claudia.maier@oregonstate.edu \\ 5 Linus Pauling Institute, Department of Biochemistry and Biophysics, Oregon State University, Corvallis, \\ OR 97331, USA \\ * Correspondence: adrian.gombart@oregonstate.edu; Tel.: +1-541-737-8018
}

Received: 5 February 2019; Accepted: 5 March 2019; Published: 9 March 2019

\begin{abstract}
Xanthohumol (XN), a prenylated flavonoid found in hops, inhibits growth in a variety of cancer cell lines; however, its use raises concerns as gut microbiota and the host's hepatic cytochrome P450 enzymes metabolize it into the most potent phytoestrogen known, 8-prenylnaringenin (8-PN). The XN derivatives dihydroxanthohumol (DXN) and tetrahydroxanthohumol (TXN) are not metabolized into 8-PN and they show higher tissue concentrations in vivo compared with $\mathrm{XN}$ when orally administered to mice at the same dose. Here we show that DXN and TXN possess improved anti-proliferative activity compared with XN in two colon (HCT116, HT29) and two hepatocellular (HepG2, Huh7) carcinoma cell lines, as indicated by their respective $\mathrm{IC}_{50}$ values. Furthermore, $\mathrm{XN}$, DXN, and TXN induce extensive apoptosis in all these carcinoma cell lines. Finally, TXN induces $\mathrm{G}_{0} / \mathrm{G}_{1}$ cell cycle arrest in the colon carcinoma cell line HT29. Our findings suggest that DXN and TXN could show promise as therapeutic agents against colorectal and liver cancer in preclinical studies without the drawback of metabolism into a phytoestrogen.
\end{abstract}

Keywords: xanthohumol; polyphenol; flavonoid; apoptosis; colon cancer; dihydroxanthohumol; tetrahydroxanthohumol; cell cycle; phytochemical; chemoprevention; dietary agent

\section{Introduction}

First discovered at the turn of the twentieth century by Power et al., $\mathrm{XN}$ is a simple prenylated flavonoid found in the female inflorescences, or hop cones, of the hop plant Humulus lupulus [1]. Hops are used to add flavor, color, and bitterness to beer. Since hops are rarely used in a culinary setting, beer represents the main dietary source of XN. Extensive studies show $\mathrm{XN}$ inhibits cancer cell growth in vitro, and reduces weight gain and improves cognitive function in vivo [2-9]. Nevertheless, despite these positive effects, the use of $\mathrm{XN}$ raises concerns, as it was shown both in vitro and in vivo that $\mathrm{XN}$ is metabolized into 8-prenylnaringenin (8-PN), the most potent phytoestrogen currently known [10]. 
Synthesis of $\mathrm{XN}$ from phloracetophenone is inefficient [11]; therefore, $\mathrm{XN}$ is currently isolated from $\mathrm{CO}_{2}$-extracted hops, a byproduct of the hops industry, which provides a less expensive alternative to synthesis [2]. Because of the inexpensive production of $\mathrm{XN}$ and its purported health benefits, it is marketed as a dietary supplement. Preclinical animal studies show that $\mathrm{XN}$ is safe in high doses. Female BALB/c mice fed XN at $1000 \mathrm{mg} / \mathrm{kg}$ body weight for three weeks exhibited no adverse effects on major organ function and homoeostasis [12]. Furthermore, Sprague Dawley rats treated with $1000 \mathrm{mg} / \mathrm{kg}$ body weight per day by oral gavage showed only weak hepatotoxicity and poor development of mammary glands, neither of which are fatal [13]. In humans, an escalating dose study was performed in menopausal women using an extract from hops rich in $\mathrm{XN}$. The results showed that the extract does not affect the sex hormones estradiol, follicle stimulating hormone, or luteinizing hormone, does not affect blood clotting, and caused no acute toxicity [14].

Previous studies show that $\mathrm{XN}$ readily isomerizes to isoxanthohumol (IX), which is the first step in the metabolism of XN (Figure 1, pathway 1). This isomerization is enhanced by the high temperatures used during wort boiling [15]. It also occurs in the stomach, due to the acidic conditions encountered there [16]. After isomerization, the gut microbiome and the host's hepatic cytochrome P450 enzymes metabolize IX into 8-PN [10]. A previous study showed Eubacterium limosum metabolizes IX via $O$-demethylation (Figure 1, pathway 2) [17]. Up to $34 \%$ of $X N$ entering the gut can be converted to 8-PN; therefore, the microbiome plays a significant role in the formation of 8-PN from XN and IX. [18]. Our own research group recently discovered that E. ramulus metabolizes $\mathrm{XN}$ into DXN, and 8-PN into $O$-desmethylxanthohumol and $O$-desmethyl- $\alpha, \beta$-dihydroxanthohumol [19]. On the other hand, both DXN and TXN differ from XN in that they lack the $\alpha, \beta$-unsaturated ketone found in XN; therefore, interconversion to $\mathrm{XN}$ or IX is not metabolically possible [3]. This property prevents the formation of 8-PN, one of the most potent phytoestrogens known (Figure 1) [3,20,21]. Interestingly, 8-PN possesses anti-proliferative effects in vitro against the colon carcinoma cell line Caco-2, breast carcinoma line MCF-7, the melanoma line SK-MEL-28, and a Burkitt lymphoma cell line [21-25]. The estrogenic effects of 8-PN also show promising clinical results in treating postmenopausal symptoms, but these studies are usually short term and were not designed to assess the effect of potential cancer promoting properties [26]. In the host, 8-PN acts as a strong agonist for estrogen receptors located in cells throughout the body, which could increase one's risk of developing hormone-dependent cancers $[27,28]$. Thus, its estrogenic activity is of concern and additional studies to assess the safety of 8-PN in long-term supplementation are needed [26].

In vitro, $\mathrm{XN}$ inhibits proliferation of breast, colon, hepatocellular, ovarian, pancreatic, prostate, and medullary thyroid cancer cell lines [5,9,29-38]. Treatment of four hepatocellular carcinoma cell lines-Huh-7, HepG2, Hep3B, and SK-Hep-1-with XN decreased both viability and colony forming ability [39]. XN also caused dose-dependent cytotoxic effects in colon carcinoma cell lines HT29, HCT15, and 40-16 [5,36,40]. Several apoptotic mechanisms were identified in the various cell types. In 40-16 cells, $\mathrm{XN}$ activates the death receptor and mitochondrial apoptosis pathway [36]; however, in HCT116 cells, XN induces apoptosis through PKA inhibition via upregulation of adenylate cyclase, while HT29 cells appeared insensitive to XN toxicity [41]. In the metastatic colon carcinoma line SW620, XN was proposed to act as a mitocan, because it induces apoptosis by impairing mitochondrial function [42]. On the other hand, in the hepatocellular carcinoma line HepG2, XN induces apoptosis through the NF-kB/p53-apoptosis signaling pathway [43].

Here we demonstrate the anti-proliferative and cytotoxic effects of $\mathrm{XN}$ in two human colon adenocarcinoma cell lines (HT29 and HCT116) and two human hepatocellular carcinoma cell lines (HepG2 and Huh7). Furthermore, we show for the first time that DXN and TXN possess similar effects, and in most cases, a lower half-maximal growth inhibitory concentration $\left(\mathrm{IC}_{50}\right)$ than $\mathrm{XN}$ in these cell types. While XN and DXN do not appear to induce cell cycle arrest, HT29 cells treated with TXN arrest in the $G_{0} / G_{1}$ phase of the cell cycle. These findings demonstrate that the two non-estrogenic $X N$ derivatives are attractive alternatives to test along with $\mathrm{XN}$ in future preclinical studies using mouse models of colorectal and hepatocellular carcinoma. 


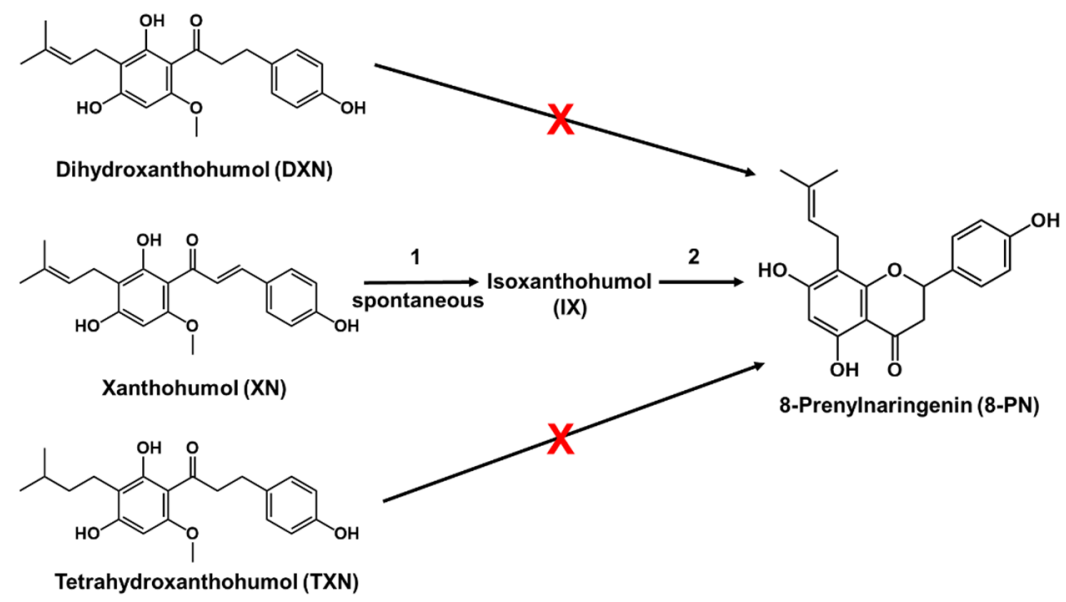

Figure 1. Structural comparison of dihydroxanthohumol (DXN), tetrahydroxanthohumol (TXN), xanthohumol $(\mathrm{XN})$, and 8-prenylnaringenin (8-PN). Xanthohumol is converted to 8-prenylnaringenin in a two-step process. In step 1, xanthohumol spontaneously isomerizes to isoxanthohumol (IX). In step 2, isoxanthohumol is converted to 8-prenylnaringenin by the gut microbiome, or cytochrome P450 enzymes of the host $[10,18]$. XN can be converted into DXN by gut microbiota [19]. 8-PN formation is not possible with DXN or TXN. Figure adapted from [3].

\section{Results}

\subsection{XN, DXN, and TXN Inhibit Proliferation of Human Colon Adenocarcinoma and Liver Carcinoma Cell Lines}

The half maximal inhibitory concentration $\left(\mathrm{IC}_{50}\right)$ of $\mathrm{DXN}$ and $\mathrm{TXN}$ for two colon carcinoma and two hepatocellular carcinoma cell lines was determined using the SRB colorimetric assay for cytotoxicity screening, as previously described [44]. Table 1 lists the $\mathrm{IC}_{50}$ values experimentally determined for XN, DXN, and TXN in the colon carcinoma cell lines HCT116 and HT29, and the hepatocellular carcinoma cell lines HepG2 and Huh7. DXN and TXN (except HepG2) exhibited lower $\mathrm{IC}_{50}$ values than XN. For the cells most sensitive to DXN and TXN, the decrease in $\mathrm{IC}_{50}$ values was approximately 30\% compared to XN (Table 1). In HepG2 cells, TXN was slightly less potent at inhibiting cell proliferation compared to $\mathrm{XN}$, as indicated by a higher $\mathrm{IC}_{50}$ value (Table 1 ). Compared to DXN, TXN was more potent at inhibiting proliferation in Huh7 cells, as indicated by a lower $\mathrm{IC}_{50}$ value, whereas DXN was more potent in the other three cell lines (Table 1). HT29 was less sensitive (highest $\mathrm{IC}_{50}$ value) to $\mathrm{XN}$ treatment than HCT116, but showed a similar sensitivity to the derivatives DXN and TXN as HCT116 (Table 1).

Table 1. XN, DXN, and TXN inhibit proliferation of human colon adenocarcinoma (HCT116 and HT29) and liver carcinoma (HepG2 and Huh7) cell lines. Mean $\mathrm{IC}_{50}$ values $( \pm \mathrm{SD})$ were calculated from cell growth curves ( $n=5$, Figure $\mathrm{S} 1)$.

\begin{tabular}{ccccccc}
\hline \multirow{2}{*}{ Cell Type } & \multicolumn{7}{c}{ IC $_{50}(\mu \mathrm{M})$} \\
\cline { 2 - 7 } & XN & SD & DXN & SD & TXN & SD \\
\hline HCT116 & 40.8 & 1.4 & $28.7^{\mathrm{a}}$ & 1.0 & $34.0^{\mathrm{b}}$ & 1.3 \\
HT29 & 50.2 & 1.4 & $31.4^{\mathrm{a}}$ & 1.1 & $34.9^{\mathrm{b}}$ & 1.1 \\
HepG2 & 25.4 & 1.1 & $21.7^{\mathrm{a}}$ & 1.1 & $27.1^{\mathrm{b}}$ & 1.1 \\
Huh7 & 37.2 & 1.5 & $32.5^{\mathrm{a}}$ & 1.3 & $26.5^{\mathrm{b}}$ & 1.1
\end{tabular}

a Statistically significantly different from XN treatment $p<0.05) ;{ }^{\mathrm{b}}$ Statistically significantly different from $\mathrm{XN}$ and DXN $(p<0.05)$. Statistical analysis was performed using one-way ANOVA with a Sidak's post hoc test. 


\section{2. $X N$ and Derivatives Induce Apoptosis}

The Annexin V assay distinguishes the early apoptotic stage from the late necrotic state. Externalization of phosphatidyl serine, an early marker of apoptosis, was detected by flow cytometry after staining with Annexin V-PE and 7AAD. HT29 cells were treated for $18 \mathrm{~h}$ with either vehicle control, XN, DXN, or TXN. All compounds significantly induced apoptosis dose-dependently in these cells, compared to vehicle control (Figure 2). At $18 \mathrm{~h}$ post treatment, more DXN- and TXN-treated cells were in early apoptosis, whereas more $\mathrm{XN}$-treated cells were in late apoptosis.
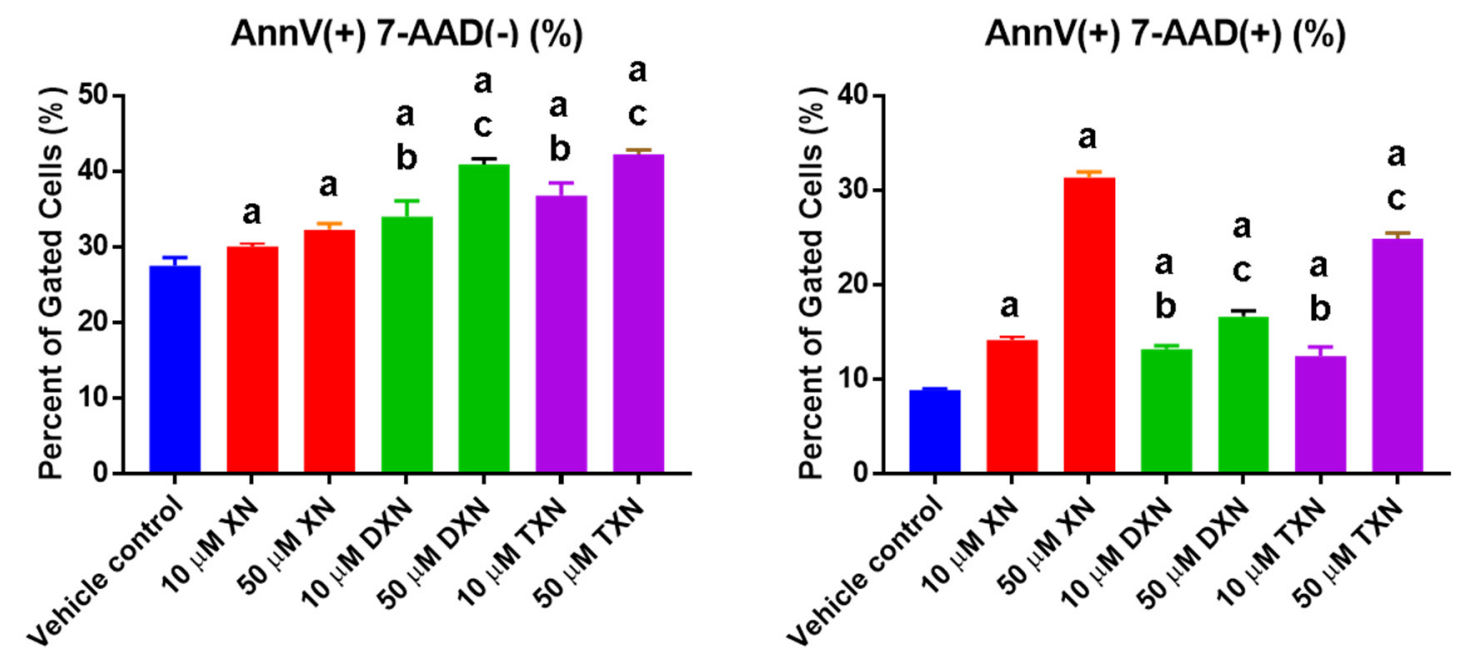

Figure 2. XN, DXN, and TXN induce apoptosis in HT29 cells. Cells were treated with each prenylated flavonoid at the concentration indicated $(10$ or $50 \mu \mathrm{M})$, and apoptosis was detected using an Annexin $\mathrm{V}$ assay. Externalization of phosphatidyl serine, an early marker of apoptosis, was detected by flow cytometry after staining with Annexin V-PE and 7-AAD. Annexin $\left.\mathrm{V}^{+}\right)$7-AAD $\left(^{-}\right)$cells are undergoing early apoptosis (left panel), and Annexin $\left.\mathrm{V}^{+}\right)$7-AAD $\left(^{+}\right)$are undergoing late apoptosis (right panel). Values are mean $\pm \mathrm{SD}, n=9$ for each treatment. The letter "a" indicates a statistically significant difference from vehicle control, the letter " $\mathrm{b}$ " indicates a statistically significant difference from $10 \mu \mathrm{M}$ $\mathrm{XN}$, and the letter " $\mathrm{c}$ " indicates a statistically significant difference from $50 \mu \mathrm{M} \mathrm{XN}(p<0.05)$. Statistical analysis was performed using one-way ANOVA with a Sidak's post hoc test.

Induction of apoptosis was confirmed by measuring activation of caspase enzymes. In HT29 cells (Figure 3), treatment with $\mathrm{XN}$ and its derivatives for $18 \mathrm{~h}$ resulted in a dose-dependent increase in cells undergoing the early stages of apoptosis (SR-VAD-FMK $\left(^{+}\right)$7-AAD $\left({ }^{-}\right)$), indicating caspase activation without membrane alterations (early- to mid-stage apoptosis). In addition, there was a statistically significant increase in doubly stained SR-VAD-FMK $\left.\left({ }^{+}\right) 7-\mathrm{AAD}^{+}\right)$cells, indicating cells in late apoptosis (Figure 3).

At $18 \mathrm{~h}$ post treatment, more DXN- and TXN-treated cells were in early- to mid-apoptosis, whereas more $\mathrm{XN}$-treated cells were in late apoptosis. Taken together, the data from both assays suggest that XN may promote a slightly more rapid apoptosis than DXN or TXN in HT29 cells.

Quantifying the total number of dead and apoptotic cells from the caspase assay showed that DXN induced slightly less apoptosis $(-7.2 \%)$, while TXN induced slightly greater apoptosis $(+7.1 \%)$ than XN (Figure 4). 
SR-VAD-FMK(+) 7-AAD(-) (\%)

SR-VAD-FMK(+) 7-AAD(+) (\%)
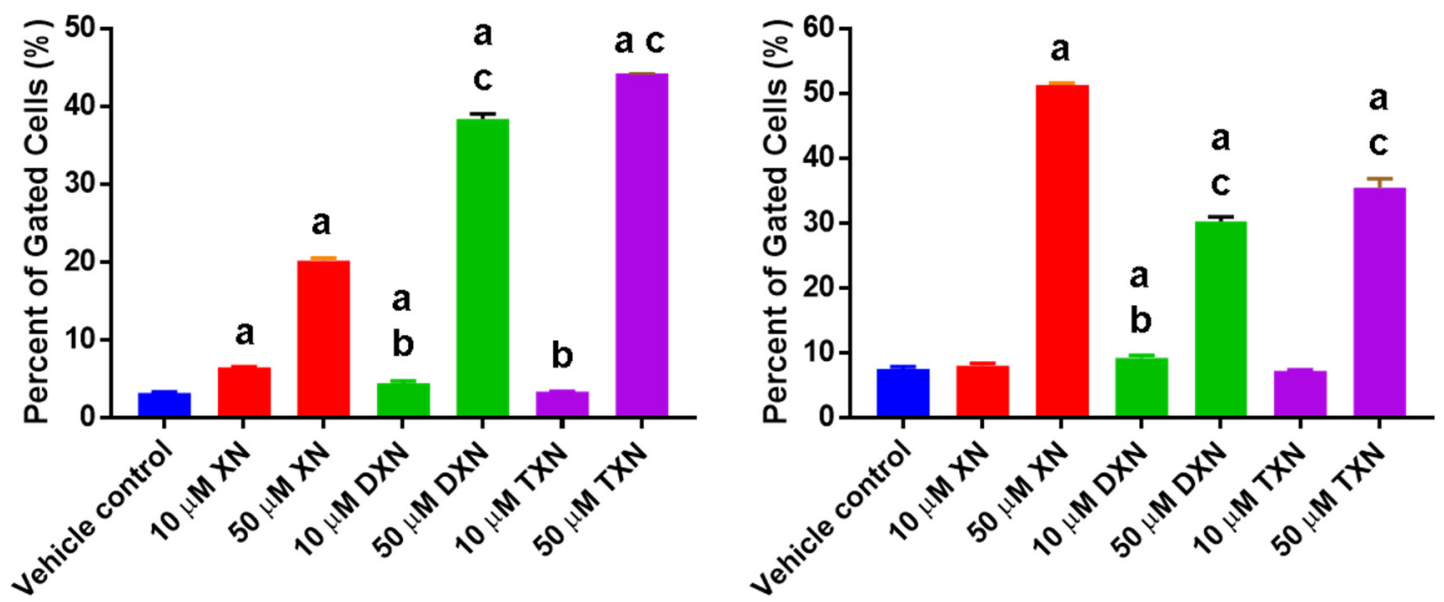

Figure 3. XN, DXN, and TXN induce caspase activation, cellular plasma membrane permeabilization, and cell death in HT29 cells. Cells were treated with each prenylated flavonoid at the concentration indicated $(10$ or $50 \mu \mathrm{M})$ for $18 \mathrm{~h}$ and apoptosis was detected using the multicaspase assay. Apoptosis was detected by flow cytometry after staining with SR-VAD-FMK and 7-AAD. SR-VAD-FMK $\left(^{+}\right)$ 7-AAD $\left(^{-}\right)$cells are undergoing early- to mid-apoptosis (left panel), and SR-VAD-FMK $\left(^{+}\right)$7-AAD $\left(^{+}\right)$ are undergoing late apoptosis (right panel). Values are mean $\pm \mathrm{SD}, n=9$ for each treatment. The letter " $a$ " indicates a statistically significant difference from vehicle control, the letter " $b$ " indicates a statistically significant difference from $10 \mu \mathrm{M} \mathrm{XN}$, and the letter " $c$ " indicates a statistically significant difference from $50 \mu \mathrm{M} \mathrm{XN}(p<0.05)$. Statistical analysis was performed using one-way ANOVA with a Sidak's post hoc test.

Total apoptotic cells

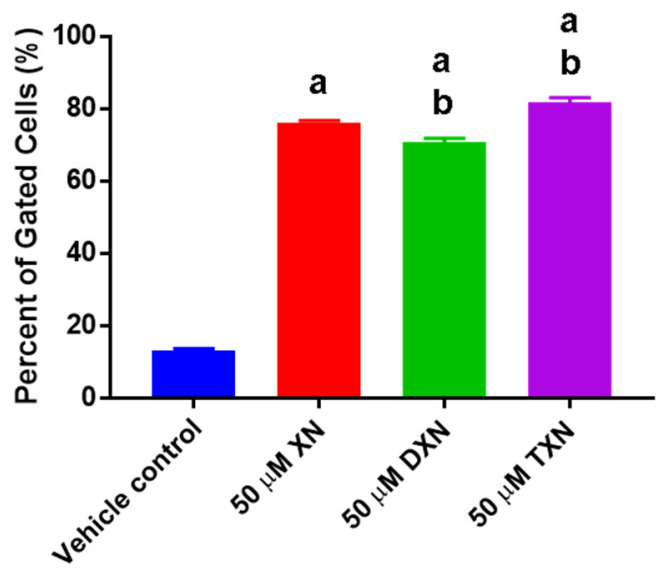

Figure 4. Total percentage of apoptotic and dead cells. Values are mean $\pm \mathrm{SD}, n=9$ for each condition. The letter " $a$ " indicates a statistically significant difference from vehicle control, the letter " $b$ " indicates a statistically significant difference from $50 \mu \mathrm{M}$ XN $(p<0.05)$. Statistical analysis was performed using one-way ANOVA with a Sidak's post hoc test.

\subsection{TXN Induces a $G_{1}$ Cell Cycle Arrest in HT29 Cells}

We treated HT29 cells for $24 \mathrm{~h}$ following cell cycle synchronization by serum starvation, and performed cycle analysis with propidium iodide staining. Results showed that only TXN induced a statistically significant cell cycle arrest in these cells, as indicated by an increased accumulation of cells in the $\mathrm{G}_{1}$ phase (Figure 5). All prenylated flavonoids induced cell apoptosis, as indicated by a sub $\mathrm{G}_{0} / \mathrm{G}_{1}$ population of $82 \%, 60 \%$, and $45 \%$ in the cells treated with $\mathrm{XN}, \mathrm{DXN}$, and $\mathrm{TXN}$, respectively. 


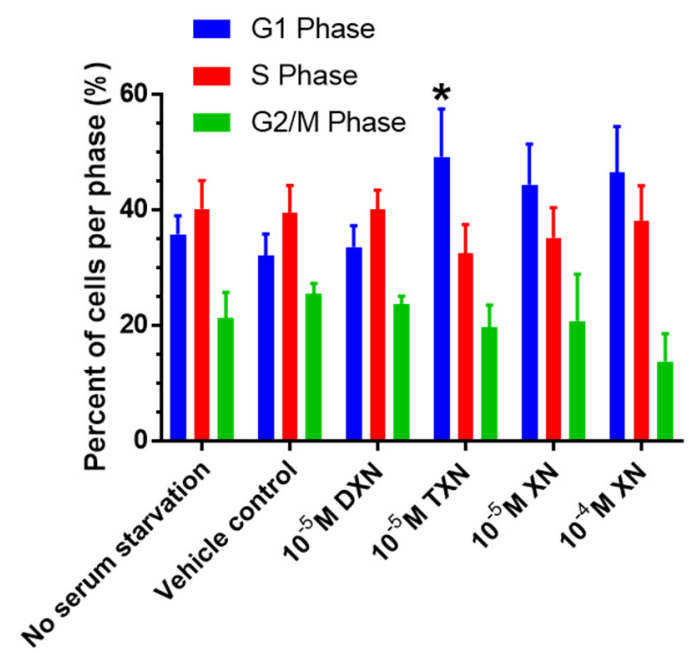

Figure 5. Cell cycle analysis using HT29 cells and propidium iodide, values are mean \pm SD, $n=9$ for each treatment. An asterisk indicates a statistically significant difference from vehicle control $(p<0.05)$. Statistical analysis was performed using one-way ANOVA with a Sidak's post hoc test.

\section{Discussion}

In the United States, colorectal cancer is the third most common cause of cancer-related death [45] and it is the second leading cause of cancer-related deaths in the developed world [46,47]. The incidence of liver cancer has tripled since 1980, mortality has doubled during that time, and it is the fifth most common cause of cancer death in the United States. [45]. For both cancers, it is imperative to discover new compounds for prevention and treatment. The prenylated flavonoid $\mathrm{XN}$ was previously shown to inhibit the growth of the colon cancer cell lines HT-29 and 40-16 in a dose-dependent manner [5,36]. $\mathrm{XN}$ also induced apoptosis in the liver carcinoma cell lines HepG2 and Huh7 in a dose-dependent manner [39]. In the current study, we determined IC $_{50}$ values of $40.8 \pm 1.4,50.2 \pm 1.4,25.4 \pm 1.1$, and $37.2 \pm 1.5 \mu \mathrm{M}$ for XN, in HCT116, HT29, HepG2, and Huh7 cell lines, respectively. These results indicate that both hepatocellular and colon carcinoma cells are sensitive to growth inhibition by $\mathrm{XN}$. The $\mathrm{IC}_{50}$ values determined for HepG2 and Huh7 cells in this study were, on average, three-fold lower than those calculated for the hepatocellular carcinoma cells HA22T/VGH and Hep3B, but still in the micromolar range [48]. In this study, the $\mathrm{IC}_{50}$ values determined for HT29 and HCT116 were higher than those determined for the HCT15 and 40-16 colon carcinoma cell lines [36,40]. The differences in in vitro sensitivity with the different cell lines could have implications for preventative treatments, but this would require experiments with in vivo xenograft models in mice to determine. It is interesting to note that Shikata et al. (2017) showed the sensitivity of the HCT116 and SW480 colon cancer cell lines to $\mathrm{XN}$, with $\mathrm{IC}_{50}$ values in the micromolar range in vitro, reflected by their in vivo sensitivity in a xenograft model [41]. While we found that HT29 and HCT116 cells were both sensitive to treatment with XN and its derivatives, HT29 was less sensitive than HCT116. This is consistent with a previous study by Shikata et al. (2017) that determined HT29 cells were insensitive compared to HCT116 cells by measuring the sub- $\mathrm{G}_{1}$ population after treatment [41]. Although considered insensitive, HT29 was still affected by $\mathrm{XN}$ treatment, but required a higher dose before showing cytotoxicity. In their cell cycle assay, the highest dose was $30 \mu \mathrm{M}$, whereas we used $50 \mu \mathrm{M}$. It is possible that Shikata et al. (2017) would have observed an increased sub- $\mathrm{G}_{1}$ population if they had used this dose. In addition, our study concurs with those performed previously by others, who observed that HT29 cells are sensitive to $\mathrm{XN}$ treatment, but were the least sensitive of several cancer cell lines tested as reflected by a higher $\mathrm{IC}_{50}[5,49,50]$. It is possible to attribute the differences between studies to experimental design, cell density, or different culture conditions. Taken together, the findings indicate that $\mathrm{XN}$ is cytotoxic to various colon and liver cancer cell lines. 
$\mathrm{XN}$ is metabolized into the potent phytoestrogen 8-PN via conversion into IX (Figure 1). We recently demonstrated that DXN and TXN are non-estrogenic, as these derivatives lack the $\alpha, \beta$-unsaturated ketone found in $\mathrm{XN}$; therefore, interconversion to $\mathrm{XN}$ or IX is not metabolically possible [3]. This property prevents the formation of 8-PN [3,20,21]. Like XN, DXN possesses anti-proliferative activity in HT29 colon cancer and MCF7 breast cancer cell lines [51,52]. The $\mathrm{IC}_{50}$ value of DXN in HT29 cells was previously determined to range from 12 to $74 \mu \mathrm{M}$ [51,52]. In the current study, we calculated a comparable $\mathrm{IC}_{50}$ value of $31.4 \pm 1.1 \mu \mathrm{M}$. We observed that in all the cell lines tested, both DXN and TXN inhibited cellular growth, as well as XN. For most cell types, DXN and TXN were slightly more potent than XN. Out of the three compounds tested, TXN was the only compound that induced cell cycle arrest in the $\mathrm{G}_{1}$ phase.

While all prenylated flavonoids tested induced apoptosis in HT29 cells, XN appeared to increase the rate of apoptosis. After $18 \mathrm{~h}$, cells treated with DXN or TXN showed a slightly greater percentage undergoing early- to mid-apoptosis, and a slightly lower percentage of cells undergoing late apoptosis, compared to XN treatment. Nevertheless, when HT29 cells were treated with a $50 \mu \mathrm{M}$ concentration of the prenylated flavonoids, the total number of dead or apoptotic cells was slightly greater in HT29 cells treated with TXN. Taken together, our data suggest that XN and its derivatives inhibit cancer cell proliferation through a molecular mechanism that includes caspase-mediated apoptosis.

Oral consumption of $\mathrm{XN}$ and its derivatives is expected to expose the intestinal cell layer to the highest concentrations. After initial uptake in the intestine, $\mathrm{XN}$ is transported to the liver through the portal vein. In the liver, $\mathrm{XN}$ is glucuronidated $[53,54]$. This conjugation significantly lowers the amount of XN found in other tissues $[53,55,56]$. In a study of metabolic syndrome and obesity, our research group observed that when added to the diet ( $30 \mathrm{mg} / \mathrm{kg}$ body weight), the concentrations of XN, DXN, and TXN were highest in the liver, with DXN and TXN 5- to 7-fold higher than total XN, which included conjugated forms and IX [3]. The tissue levels of XN and its derivatives ranged from 0.3-3.0 $\mu \mathrm{M}$. We would expect much higher concentrations in the colon. In this same study, we noted that levels of DXN and TXN did not induce markers of hepatotoxicity, i.e., plasma aspartate aminotransferase (AST) or alanine aminotransferase (ALT), in control or treated mice [3]. In colon cancer xenograft models with mice, Shikata et al. (2017) injected XN IP daily for 17 days and observed a dramatic and significant reduction in tumor growth in SW480 and about a 2-3-fold reduction in tumor volume for HCT116 at doses of 1,15 , and $30 \mathrm{mg} / \mathrm{kg}$ body weight. They observed no changes in mouse body weight. Furthermore, administration of $\mathrm{XN}$ in xenograft models of breast, leukemia, prostate, pancreatic, gastric, and cholangiocarcinoma cells inhibits tumor growth [29,41,57-63]. Taken together, these data suggest that $\mathrm{XN}$ and its derivatives show promise in future studies. Because of its well-established anti-proliferative effects in cell culture and safety in preclinical studies, $\mathrm{XN}$ and its non-estrogenic derivatives are reasonable candidates for preclinical studies of colorectal and liver cancer, which is relatively untested even for $\mathrm{XN}$, since the discovery of its anti-proliferative effects 20 years ago [5].

In future work, we will test XN, DXN, and TXN as potential treatments of colorectal and hepatocellular carcinoma using mouse models and further elucidate the molecular mechanisms by which these derivatives mediate their effects. Our findings suggest that these plant-derived molecules show promise as potential anticancer compounds.

\section{Materials and Methods}

\subsection{Cell Culture}

The human colon adenocarcinoma cell lines HT 29 and HCT116 were provided by Dr. H. Phillip Koeffler (Cedars-Sinai Medical Center, Los Angeles, CA, USA). The human liver carcinoma cell line HepG2 was provided by Dr. Tori Hagen (Oregon State University, Corvallis, OR, USA). We purchased Huh7 from the American Type Tissue Collection (ATCC, Manassas, VA, USA). The other cancer cell lines were originally purchased from ATCC. All cancer cell lines were grown and maintained in Dulbecco's Modified Eagle's Medium (DMEM) without sodium pyruvate (Corning, 
Manassas, VA, USA) supplemented with 10\% fetal bovine serum (Hyclone, Logan, UT, USA) and 1\% penicillin-streptomycin (Gibco, Grand Island, NY, USA). All cell types were maintained in $5 \% \mathrm{CO}_{2}$ at $37^{\circ} \mathrm{C}$ with humidity.

\subsection{Treatments}

$\mathrm{XN}$ and TXN were provided by Hopsteiner Inc., while DXN was synthesized as described previously [3]. The purity and identity of the prenylated flavonoids $X N, D X N$, and TXN, were determined by mass and NMR spectrometry [3]. All prenylated flavonoids were dissolved in 100\% ethanol and added to the culture medium at a final concentration of 1-100 $\mu \mathrm{mol} / \mathrm{L}$, depending on desired treatment. Confluency of cells was approximately $50-70 \%$ at time of treatment. As a vehicle control, ethanol was added to culture medium equivalent to prenylated flavonoid treatment. Final concentration of ethanol did not exceed $0.1 \%$.

\subsection{Cellular Proliferation}

Cells were seeded into 96-well plates (15,000 cells per well). After $24 \mathrm{~h}$, cells were treated with either XN, DXN, or TXN, as described above. Cell viability was evaluated using a sulforhodamine B (SRB) assay (Sigma-Aldrich, St. Louis, MO, USA), as described previously [44]. Absorbance of dye was measured at a wavelength of $565 \mathrm{~nm}$, using a Molecular Devices SpectraMax (Molecular Devices, Sunnyvale, CA, USA) plate reader.

\subsection{Flow Cytometry}

\subsubsection{Apoptosis}

At various times after treatment with $\mathrm{XN}, \mathrm{DXN}$, or TXN, adherent and floating cells were collected for analysis. Apoptosis was assessed using flow cytometry-based annexin V (Invitrogen ${ }^{\mathrm{TM}}$. eBioscience $^{\mathrm{TM}}$ Annexin V Apoptosis Detection Kit PE, Thermo Fisher, Waltham, MA, USA) and a multicaspase assay kit (MilliporeSigma, Burlington, MA, USA). The annexin V assay is based on measurement of externalization of phosphatidyl serine, a common characteristic of cells undergoing apoptosis. The multicaspase assay is based on measurement of caspase enzymes activated during apoptosis. Cells were trypsinized, washed in Dulbecco's Phosphate Buffered Saline (D-PBS), and stained with Annexin V, sulforhodamine-valyl-alanyl-aspartyl-fluoromethyl-ketone (SR-VAD-FMK), and 7-amino-actinomycin D (7AAD) according to the manufacturer's instructions. Cell populations were quantified using a Guava personal cytometer (Guava Technologies, Burlingame, CA, USA).

\subsubsection{Cell Cycle Analysis}

At various time points after treatment with $\mathrm{XN}, \mathrm{DXN}$, or TXN, adherent and floating cells were collected and fixed in 70\% ethanol at one million cells per aliquot. Samples were centrifuged at $500 \times g$, washed with PBS, and re-suspended in cellular DNA staining solution containing $40 \mathrm{mg} / \mathrm{mL}$ propidium iodide (Sigma-Aldrich, St. Louis, MO, USA) and $100 \mathrm{mg} / \mathrm{mL}$ RNase A (Sigma-Aldrich) in PBS. After a 15-min incubation at room temperature, cell populations were quantified using a Guava personal cytometer (Guava Technologies).

\subsection{Statistical Analysis}

Statistical analyses were performed with the GraphPad Prism 7 software (GraphPad Software, Sand Diego, CA, USA). Group differences were assessed with a one-way ANOVA, followed by a Sidak's post hoc test. The Sidak's post hoc test was used to compare every mean with either the control mean, or XN mean. Statistical significance was set at $p \leq 0.05$. 
Supplementary Materials: Supplementary materials can be found at http:/ /www.mdpi.com/1422-0067/20/5/ $1203 /$ s1.

Author Contributions: I.E.L. performed all experiments. I.E.L. and A.F.G. designed the experiments, analyzed data, and wrote the manuscript. C.L.M. and M.B.L. contributed to experimental design and provided technical assistance. J.F.S provided scientific and material support. C.S.M. and J.F.S. assisted with manuscript development. All coauthors reviewed and revised the manuscript.

Funding: This research was funded by the National Institutes of Health, grant NIH/NCCIH 5R01AT009168 to A.F.G., J.F.S., and C.S.M., Hopsteiner, Inc., New York, and the Oregon State University Foundation Buhler-Wang Research Fund. I.E.L. was supported by the 2017-18 Christopher and Catherine Mathews Graduate Fellowship in the Department of Biochemistry and Biophysics, the Franz Stenzel M.D. and Kathryn Stenzel II Scholarship by the Oregon Office of Student Access and Completion, and the 2019 Audrey and George Varsevelt Linus Pauling Institute Graduate Fellowship.

Acknowledgments: We thank Hopsteiner Inc. for providing XN and TXN. We thank the Department of Biochemistry and Biophysics, and the Linus Pauling Institute at Oregon State University for their support. We thank John Molitor in the College of Public Health and Human Sciences at Oregon State University for valuable advice regarding statistical analysis, and Kelly C. Schoun.

Conflicts of Interest: The authors declare no conflict of interest. The funders had no role in the design of the study; in the collection, analyses, or interpretation of data; in the writing of the manuscript, or in the decision to publish the results.

\section{Abbreviations}

$\begin{array}{ll}\text { XN } & \text { Xanthohumol } \\ \text { DXN } & \text { Dihydroxanthohumol } \\ \text { TXN } & \text { Tetrahydroxanthohumol } \\ \text { 8-PN } & \text { 8-Prenylnaringenin } \\ \text { IX } & \text { Isoxanthohumol } \\ \text { 7AAD } & \text { 7-amino-actinomycin D } \\ \text { SR-VAD-FMK } & \text { Sulforhodamine-valyl-alanyl-aspartyl-fluoromethyl-ketone } \\ \text { DMEM } & \text { Dulbecco's Modified Eagle Media } \\ \text { D-PBS } & \text { Dulbecco's Phosphate-Buffered Saline }\end{array}$

\section{References}

1. Power, F.B.; Tutin, F.; Rogerson, H. CXXXV-The constituents of hops. J. Chem. Soc. Trans. 1913, 103, 1267-1292. [CrossRef]

2. Stevens, J.F.; Page, J.E. Xanthohumol and related prenylflavonoids from hops and beer: To your good health! Phytochemistry 2004, 65, 1317-1330. [CrossRef] [PubMed]

3. Miranda, C.L.; Johnson, L.A.; de Montgolfier, O.; Elias, V.D.; Ullrich, L.S.; Hay, J.J.; Paraiso, I.L.; Choi, J.; Reed, R.L.; Revel, J.S.; et al. Non-estrogenic Xanthohumol Derivatives Mitigate Insulin Resistance and Cognitive Impairment in High-Fat Diet-induced Obese Mice. Sci. Rep. 2018, 8, 613. [CrossRef] [PubMed]

4. Zamzow, D.R.; Elias, V.; Legette, L.L.; Choi, J.; Stevens, J.F.; Magnusson, K.R. Xanthohumol improved cognitive flexibility in young mice. Behav. Brain Res. 2014, 275, 1-10. [CrossRef] [PubMed]

5. Miranda, C.L.; Stevens, J.F.; Helmrich, A.; Henderson, M.C.; Rodriguez, R.J.; Yang, Y.H.; Deinzer, M.L.; Barnes, D.W.; Buhler, D.R. Antiproliferative and cytotoxic effects of prenylated flavonoids from hops (Humulus lupulus) in human cancer cell lines. Food Chem. Toxicol. 1999, 37, 271-285. [CrossRef]

6. Miranda, C.L.; Aponso, G.L.; Stevens, J.F.; Deinzer, M.L.; Buhler, D.R. Prenylated chalcones and flavanones as inducers of quinone reductase in mouse Hepa 1c1c7 cells. Cancer Lett. 2000, 149, 21-29. [CrossRef]

7. Henderson, M.C.; Miranda, C.L.; Stevens, J.F.; Deinzer, M.L.; Buhler, D.R. In vitro inhibition of human P450 enzymes by prenylated flavonoids from hops, Humulus lupulus. Xenobiotica 2000, 30, 235-251. [CrossRef] [PubMed]

8. Miranda, C.L.; Yang, Y.H.; Henderson, M.C.; Stevens, J.F.; Santana-Rios, G.; Deinzer, M.L.; Buhler, D.R. Prenylflavonoids from hops inhibit the metabolic activation of the carcinogenic heterocyclic amine 2-amino-3-methylimidazo[4,5-f]quinoline, mediated by cDNA-expressed human CYP1A2. Drug Metab. Dispos. 2000, 28, 1297-1302. 
9. Colgate, E.C.; Miranda, C.L.; Stevens, J.F.; Bray, T.M.; Ho, E. Xanthohumol, a prenylflavonoid derived from hops induces apoptosis and inhibits NF-kappaB activation in prostate epithelial cells. Cancer Lett. 2007, 246, 201-209. [CrossRef]

10. Guo, J.; Nikolic, D.; Chadwick, L.R.; Pauli, G.F.; van Breemen, R.B. Identification of human hepatic cytochrome P450 enzymes involved in the metabolism of 8-prenylnaringenin and isoxanthohumol from hops (Humulus lupulus L.). Drug Metab. Dispos. 2006, 34, 1152-1159. [CrossRef]

11. Khupse, R.S.; Erhardt, P.W. Total synthesis of xanthohumol. J. Nat. Prod. 2007, 70, 1507-1509. [CrossRef] [PubMed]

12. Dorn, C.; Bataille, F.; Gaebele, E.; Heilmann, J.; Hellerbrand, C. Xanthohumol feeding does not impair organ function and homoeostasis in mice. Food Chem. Toxicol. 2010, 48, 1890-1897. [CrossRef] [PubMed]

13. Hussong, R.; Frank, N.; Knauft, J.; Ittrich, C.; Owen, R.; Becker, H.; Gerhauser, C. A safety study of oral xanthohumol administration and its influence on fertility in Sprague Dawley rats. Mol. Nutr. Food Res. 2005, 49, 861-867. [CrossRef] [PubMed]

14. van Breemen, R.B.; Yuan, Y.; Banuvar, S.; Shulman, L.P.; Qiu, X.; Alvarenga, R.F.; Chen, S.N.; Dietz, B.M.; Bolton, J.L.; Pauli, G.F.; et al. Pharmacokinetics of prenylated hop phenols in women following oral administration of a standardized extract of hops. Mol. Nutr. Food Res. 2014, 58, 1962-1969. [CrossRef] [PubMed]

15. Stevens, J.F.; Taylor, A.W.; Clawson, J.E.; Deinzer, M.L. Fate of xanthohumol and related prenylflavonoids from hops to beer. J. Agric. Food Chem. 1999, 47, 2421-2428. [CrossRef] [PubMed]

16. Nikolic, D.; Li, Y.; Chadwick, L.R.; Pauli, G.F.; van Breemen, R.B. Metabolism of xanthohumol and isoxanthohumol, prenylated flavonoids from hops (Humulus lupulus L.), by human liver microsomes. J. Mass Spectrom. 2005, 40, 289-299. [CrossRef] [PubMed]

17. Possemiers, S.; Rabot, S.; Espin, J.C.; Bruneau, A.; Philippe, C.; Gonzalez-Sarrias, A.; Heyerick, A.; Tomas-Barberan, F.A.; De Keukeleire, D.; Verstraete, W. Eubacterium limosum activates isoxanthohumol from hops (Humulus lupulus L.) into the potent phytoestrogen 8-prenylnaringenin in vitro and in rat intestine. J. Nutr. 2008, 138, 1310-1316. [CrossRef]

18. Possemiers, S.; Heyerick, A.; Robbens, V.; De Keukeleire, D.; Verstraete, W. Activation of proestrogens from hops (Humulus lupulus L.) by intestinal microbiota; conversion of isoxanthohumol into 8-prenylnaringenin. J. Agric. Food Chem. 2005, 53, 6281-6288. [CrossRef]

19. Paraiso, I.L.; Plagmann, L.S.; Yang, L.; Zielke, R.; Gombart, A.F.; Maier, C.S.; Sikora, A.E.; Blakemore, P.R.; Stevens, J.F. Reductive Metabolism of Xanthohumol and 8-Prenylnaringenin by the Intestinal Bacterium Eubacterium ramulus. Mol. Nutr. Food Res. 2019, 63, e1800923. [CrossRef]

20. Diel, P.; Thomae, R.B.; Caldarelli, A.; Zierau, O.; Kolba, S.; Schmidt, S.; Schwab, P.; Metz, P.; Vollmer, G. Regulation of gene expression by 8-prenylnaringenin in uterus and liver of Wistar rats. Planta Med. 2004, 70, 39-44. [CrossRef]

21. Milligan, S.; Kalita, J.; Pocock, V.; Heyerick, A.; De Cooman, L.; Rong, H.; De Keukeleire, D. Oestrogenic activity of the hop phyto-oestrogen, 8-prenylnaringenin. Reproduction 2002, 123, 235-242. [CrossRef] [PubMed]

22. Venturelli, S.; Niessner, H.; Sinnberg, T.; Berger, A.; Burkard, M.; Urmann, C.; Donaubauer, K.; Bocker, A.; Leischner, C.; Riepl, H.; et al. 6- and 8-Prenylnaringenin, Novel Natural Histone Deacetylase Inhibitors Found in Hops, Exert Antitumor Activity on Melanoma Cells. Cell Physiol. Biochem. 2018, 51, 543-556. [CrossRef] [PubMed]

23. Allsopp, P.; Possemiers, S.; Campbell, D.; Gill, C.; Rowland, I. A comparison of the anticancer properties of isoxanthohumol and 8-prenylnaringenin using in vitro models of colon cancer. Biofactors 2013, 39, 441-447. [CrossRef] [PubMed]

24. Brunelli, E.; Minassi, A.; Appendino, G.; Moro, L. 8-Prenylnaringenin, inhibits estrogen receptor-alpha mediated cell growth and induces apoptosis in MCF-7 breast cancer cells. J. Steroid Biochem. Mol. Biol. 2007, 107, 140-148. [CrossRef] [PubMed]

25. Diller, R.A.; Riepl, H.M.; Rose, O.; Frias, C.; Henze, G.; Prokop, A. Ability of prenylflavanones present in hops to induce apoptosis in a human Burkitt lymphoma cell line. Planta Med. 2007, 73, 755-761. [CrossRef] [PubMed]

26. Stulikova, K.; Karabin, M.; Nespor, J.; Dostalek, P. Therapeutic Perspectives of 8-Prenylnaringenin, a Potent Phytoestrogen from Hops. Molecules 2018, 23, 660. [CrossRef] 
27. Milligan, S.R.; Kalita, J.C.; Pocock, V.; Van De Kauter, V.; Stevens, J.F.; Deinzer, M.L.; Rong, H.; De Keukeleire, D. The endocrine activities of 8-prenylnaringenin and related hop (Humulus lupulus L.) flavonoids. J. Clin. Endocrinol. Metab. 2000, 85, 4912-4915. [CrossRef]

28. Piersen, C.E. Phytoestrogens in botanical dietary supplements: Implications for cancer. Integr. Cancer 2003, 2, 120-138. [CrossRef]

29. Monteiro, R.; Calhau, C.; Silva, A.O.; Pinheiro-Silva, S.; Guerreiro, S.; Gartner, F.; Azevedo, I.; Soares, R. Xanthohumol inhibits inflammatory factor production and angiogenesis in breast cancer xenografts. J. Cell. Biochem. 2008, 104, 1699-1707. [CrossRef]

30. Deeb, D.; Gao, X.; Jiang, H.; Arbab, A.S.; Dulchavsky, S.A.; Gautam, S.C. Growth inhibitory and apoptosis-inducing effects of xanthohumol, a prenylated chalone present in hops, in human prostate cancer cells. Anticancer Res. 2010, 30, 3333-3339.

31. Vene, R.; Benelli, R.; Minghelli, S.; Astigiano, S.; Tosetti, F.; Ferrari, N. Xanthohumol impairs human prostate cancer cell growth and invasion and diminishes the incidence and progression of advanced tumors in TRAMP mice. Mol. Med. 2012, 18, 1292-1302. [CrossRef] [PubMed]

32. Gerhauser, C.; Alt, A.; Heiss, E.; Gamal-Eldeen, A.; Klimo, K.; Knauft, J.; Neumann, I.; Scherf, H.R.; Frank, N.; Bartsch, H.; et al. Cancer chemopreventive activity of Xanthohumol, a natural product derived from hop. Mol. Cancer 2002, 1, 959-969.

33. Drenzek, J.G.; Seiler, N.L.; Jaskula-Sztul, R.; Rausch, M.M.; Rose, S.L. Xanthohumol decreases Notch1 expression and cell growth by cell cycle arrest and induction of apoptosis in epithelial ovarian cancer cell lines. Gynecol. Oncol. 2011, 122, 396-401. [CrossRef] [PubMed]

34. Cook, M.R.; Luo, J.; Ndiaye, M.; Chen, H.; Kunnimalaiyaan, M. Xanthohumol inhibits the neuroendocrine transcription factor achaete-scute complex-like 1, suppresses proliferation, and induces phosphorylated ERK1/2 in medullary thyroid cancer. Am. J. Surg. 2010, 199, 315-318, discussion 318. [CrossRef] [PubMed]

35. Dorn, C.; Weiss, T.S.; Heilmann, J.; Hellerbrand, C. Xanthohumol, a prenylated chalcone derived from hops, inhibits proliferation, migration and interleukin-8 expression of hepatocellular carcinoma cells. Int. J. Oncol. 2010, 36, 435-441. [CrossRef] [PubMed]

36. Pan, L.; Becker, H.; Gerhauser, C. Xanthohumol induces apoptosis in cultured 40-16 human colon cancer cells by activation of the death receptor- and mitochondrial pathway. Mol. Nutr. Food Res. 2005, 49, 837-843. [CrossRef]

37. Kang, Y.; Park, M.A.; Heo, S.W.; Park, S.Y.; Kang, K.W.; Park, P.H.; Kim, J.A. The radio-sensitizing effect of xanthohumol is mediated by STAT3 and EGFR suppression in doxorubicin-resistant MCF-7 human breast cancer cells. Biochim. Biophys. Acta 2013, 1830, 2638-2648. [CrossRef]

38. Kim, S.Y.; Lee, I.S.; Moon, A. 2-Hydroxychalcone and xanthohumol inhibit invasion of triple negative breast cancer cells. Chem. Biol. Interact. 2013, 203, 565-572. [CrossRef]

39. Kunnimalaiyaan, S.; Sokolowski, K.M.; Balamurugan, M.; Gamblin, T.C.; Kunnimalaiyaan, M. Xanthohumol inhibits Notch signaling and induces apoptosis in hepatocellular carcinoma. PLOS ONE 2015, 10, e0127464. [CrossRef]

40. Lee, S.H.; Kim, H.J.; Lee, J.S.; Lee, I.S.; Kang, B.Y. Inhibition of topoisomerase I activity and efflux drug transporters' expression by xanthohumol from hops. Arch. Pharm. Res. 2007, 30, 1435-1439. [CrossRef]

41. Shikata, Y.; Yoshimaru, T.; Komatsu, M.; Katoh, H.; Sato, R.; Kanagaki, S.; Okazaki, Y.; Toyokuni, S.; Tashiro, E.; Ishikawa, S.; et al. Protein kinase A inhibition facilitates the antitumor activity of xanthohumol, a valosin-containing protein inhibitor. Cancer Sci. 2017, 108, 785-794. [CrossRef] [PubMed]

42. Sastre-Serra, J.; Ahmiane, Y.; Roca, P.; Oliver, J.; Pons, D.G. Xanthohumol, a hop-derived prenylflavonoid present in beer, impairs mitochondrial functionality of SW620 colon cancer cells. Int. J. Food Sci. Nutr. 2018, 1-9. [CrossRef] [PubMed]

43. Zhao, X.; Jiang, K.; Liang, B.; Huang, X. Anticancer effect of xanthohumol induces growth inhibition and apoptosis of human liver cancer through NF-kB/p53-apoptosis signaling pathway. Oncol. Rep. 2016, 35, 669-675. [CrossRef] [PubMed]

44. Skehan, P.; Storeng, R.; Scudiero, D.; Monks, A.; McMahon, J.; Vistica, D.; Warren, J.T.; Bokesch, H.; Kenney, S.; Boyd, M.R. New colorimetric cytotoxicity assay for anticancer-drug screening. J. Natl. Cancer Inst. 1990, 82, 1107-1112. [CrossRef] [PubMed]

45. Siegel, R.L.; Miller, K.D.; Jemal, A. Cancer statistics, 2018. CA Cancer J. Clin. 2018, 68, 7-30. [CrossRef] [PubMed] 
46. Chen, C.C.; Neugut, A.I.; Rotterdam, H. Risk factors for adenocarcinomas and malignant carcinoids of the small intestine: Preliminary findings. Cancer Epidemiol. Biomark. Prev. 1994, 3, 205-207.

47. Rothwell, P.M.; Wilson, M.; Elwin, C.E.; Norrving, B.; Algra, A.; Warlow, C.P.; Meade, T.W. Long-term effect of aspirin on colorectal cancer incidence and mortality: 20-year follow-up of five randomised trials. Lancet 2010, 376, 1741-1750. [CrossRef]

48. Ho, Y.C.; Liu, C.H.; Chen, C.N.; Duan, K.J.; Lin, M.T. Inhibitory effects of xanthohumol from hops (Humulus lupulus L.) on human hepatocellular carcinoma cell lines. Phytother. Res. 2008, 22, 1465-1468. [CrossRef]

49. Hadjiolov, N.; Frank, N. Xanthohumol and sulforaphane induce apoptosis and inhibit proliferation of HT29 and HCT 116 colon cancer cells. Comptes Rendus De L Acad. Bulg. Des. Sci. 2009, 62, 1175-1182.

50. Tronina, T.; Bartmanska, A.; Milczarek, M.; Wietrzyk, J.; Poplonski, J.; Roj, E.; Huszcza, E. Antioxidant and antiproliferative activity of glycosides obtained by biotransformation of xanthohumol. Bioorg. Med. Chem. Lett. 2013, 23, 1957-1960. [CrossRef]

51. Bartmanska, A.; Tronina, T.; Poplonski, J.; Milczarek, M.; Filip-Psurska, B.; Wietrzyk, J. Highly Cancer Selective Antiproliferative Activity of Natural Prenylated Flavonoids. Molecules 2018, 23, 2922. [CrossRef] [PubMed]

52. Tronina, T.; Bartmanska, A.; Filip-Psurska, B.; Wietrzyk, J.; Poplonski, J.; Huszcza, E. Fungal metabolites of xanthohumol with potent antiproliferative activity on human cancer cell lines in vitro. Bioorg. Med. Chem. 2013, 21, 2001-2006. [CrossRef] [PubMed]

53. Wu, B.; Kulkarni, K.; Basu, S.; Zhang, S.; Hu, M. First-pass metabolism via UDP-glucuronosyltransferase: A barrier to oral bioavailability of phenolics. J. Pharm. Sci. 2011, 100, 3655-3681. [CrossRef] [PubMed]

54. Ruefer, C.E.; Gerhauser, C.; Frank, N.; Becker, H.; Kulling, S.E. In vitro phase II metabolism of xanthohumol by human UDP-glucuronosyltransferases and sulfotransferases. Mol. Nutr. Food Res. 2005, 49, 851-856. [CrossRef] [PubMed]

55. Legette, L.; Ma, L.; Reed, R.L.; Miranda, C.L.; Christensen, J.M.; Rodriguez-Proteau, R.; Stevens, J.F. Pharmacokinetics of xanthohumol and metabolites in rats after oral and intravenous administration. Mol. Nutr. Food Res. 2012, 56, 466-474. [CrossRef] [PubMed]

56. Legette, L.; Karnpracha, C.; Reed, R.L.; Choi, J.; Bobe, G.; Christensen, J.M.; Rodriguez-Proteau, R.; Purnell, J.Q.; Stevens, J.F. Human pharmacokinetics of xanthohumol, an antihyperglycemic flavonoid from hops. Mol. Nutr. Food Res. 2014, 58, 248-255. [CrossRef] [PubMed]

57. Zhang, W.; Pan, Y.; Gou, P.; Zhou, C.; Ma, L.; Liu, Q.; Du, Y.; Yang, J.; Wang, Q. Effect of xanthohumol on Th1/Th2 balance in a breast cancer mouse model. Oncol. Rep. 2018, 39, 280-288. [CrossRef]

58. Guo, D.; Zhang, B.; Liu, S.; Jin, M. Xanthohumol induces apoptosis via caspase activation, regulation of Bcl-2, and inhibition of PI3K/Akt/mTOR-kinase in human gastric cancer cells. Biomed. Pharm. 2018, 106, 1300-1306. [CrossRef]

59. Saito, K.; Matsuo, Y.; Imafuji, H.; Okubo, T.; Maeda, Y.; Sato, T.; Shamoto, T.; Tsuboi, K.; Morimoto, M.; Takahashi, H.; et al. Xanthohumol inhibits angiogenesis by suppressing nuclear factor-kappaB activation in pancreatic cancer. Cancer Sci. 2018, 109, 132-140. [CrossRef]

60. Dokduang, H.; Yongvanit, P.; Namwat, N.; Pairojkul, C.; Sangkhamanon, S.; Yageta, M.S.; Murakami, Y.; Loilome, W. Xanthohumol inhibits STAT3 activation pathway leading to growth suppression and apoptosis induction in human cholangiocarcinoma cells. Oncol. Rep. 2016, 35, 2065-2072. [CrossRef]

61. Jiang, W.; Zhao, S.; Xu, L.; Lu, Y.; Lu, Z.; Chen, C.; Ni, J.; Wan, R.; Yang, L. The inhibitory effects of xanthohumol, a prenylated chalcone derived from hops, on cell growth and tumorigenesis in human pancreatic cancer. Biomed. Pharm. 2015, 73, 40-47. [CrossRef] [PubMed]

62. Yoshimaru, T.; Komatsu, M.; Tashiro, E.; Imoto, M.; Osada, H.; Miyoshi, Y.; Honda, J.; Sasa, M.; Katagiri, T. Xanthohumol suppresses oestrogen-signalling in breast cancer through the inhibition of BIG3-PHB2 interactions. Sci. Rep. 2014, 4, 7355. [CrossRef] [PubMed]

63. Benelli, R.; Vene, R.; Ciarlo, M.; Carlone, S.; Barbieri, O.; Ferrari, N. The AKT/NF-kappaB inhibitor xanthohumol is a potent anti-lymphocytic leukemia drug overcoming chemoresistance and cell infiltration. Biochem. Pharm. 2012, 83, 1634-1642. [CrossRef] [PubMed]

(C) 2019 by the authors. Licensee MDPI, Basel, Switzerland. This article is an open access article distributed under the terms and conditions of the Creative Commons Attribution (CC BY) license (http://creativecommons.org/licenses/by/4.0/). 